University of Washington Tacoma

UW Tacoma Digital Commons

$11-15-2019$

\title{
Strategic Action for Affordable Housing: How Advocacy Organizations Accomplish Policy Change
}

Anaid Yerena

University of Washington Tacoma, yerena@uw.edu

Follow this and additional works at: https://digitalcommons.tacoma.uw.edu/urban_pub

\section{Recommended Citation}

Yerena, A. (2019). Strategic Action for Affordable Housing: How Advocacy Organizations Accomplish Policy Change. Journal of Planning Education and Research. https://doi.org/10.1177/0739456X19888000

This Article is brought to you for free and open access by the Urban Studies at UW Tacoma Digital Commons. It has been accepted for inclusion in Urban Studies Publications by an authorized administrator of UW Tacoma Digital Commons. 


\title{
Strategic Action for Affordable Housing: How Advocacy Organizations Accomplish Policy Change
}

By Anaid Yerena ${ }^{1}$

\begin{abstract}
State retrenchment, public input requirements, and local budgetary constraints make advocacy organization's (AO) work vital to the adoption and implementation of local plans. Yet, the strategies AOs use to influence policies have gone understudied in planning literature. The current study fills this gap through a case study of how AOs exert influence in planning for affordable housing in four cities in Los Angeles County. Data were collected through interviews (AO leaders and city officials), document review (AO materials), and content analysis of Housing Elements. The study found that the range of tactics depends on the political context and organizational resources.
\end{abstract}

\section{Introduction}

A significant portion of Americans (38\%) are housing cost burdened, dedicating more than 30 percent of their incomes on housing. Almost half of these (6.2 million) are defined as severely burdened, spending more than 50 percent (U.S. Housing and Urban Development [HUD] 2012). Meanwhile, renters are more than twice as likely to be classified as burdened (Joint Center for Housing Studies 2014), a problem that was exacerbated following the 2008 financial crisis (Schwartz 2015). The growth of renter households is "double the pace in any decade since the 1960s" (Joint Center for Housing Studies 2014, 4). The inevitable result is a tighter housing market with a limited supply of units and reduced vacancy rates. If they continue, these conditions will extend the current trend of increases in rents that is displacing many and contributing to homeless crises around the country. For this reason, the work that cities around the country do to plan for the creation and preservation of affordable housing, especially in larger metropolitan areas with tighter housing markets, is essential to slowing this rise in rent burdens.

Local residents and city officials agree that something must be done to address affordability problems, but residents often lack the expertise and knowledge about what is within the power

\footnotetext{
${ }^{1}$ Anaid Yerena is an assistant professor in the School of Urban Studies at the University of Washington Tacoma. Her research interests include housing and community development in the United States and Mexico, advocacy organizations, social inequality, and urban governance. Her work investigates the factors influencing local affordable housing policies and practices with a special interest in the impact of community organizations on public decision- making processes.
} 
of local governments to control. In response, advocacy organizations (AOs) have grown to play a prominent role in coming up with proposals to address the lack of affordable housing and become more adept at navigating between sectors. AOs in this study include organizations that are nonprofit housing developers, neighborhood-organizing groups, full-time housing AOs, organizations that develop policy, and those advocating for policy but that do not develop policies themselves.

Localities cannot take on the affordable housing challenge on their own; not only are they dealing with reduced resources in the wake of the Great Recession (Ross, Yan, and Johnson 2015) but also the problem requires a multipronged and context-specific approach to incentivize the creation of affordable housing (Belsky, Herbert, and Molinsky 2014; Garde 2016). One of these approaches involves the adoption and implementation of novel affordable housing policies that offer both supply and demand solutions. AOs are vital to the development and implementation of these kinds of affordable housing policies (Basolo 1997; Bratt 2012; Goetz 1995; Yerena 2015) and related services (MacIndoe and Whalen 2013). The policies AOs promote then lead the way in shaping cities' responses to affordable housing concerns.

This study was motivated by the research questions: "What type of tactics do AOs use to influence city affordable housing policymaking?" and "Why do AOs in some cities favor certain tactics over others when attempting to influence affordable housing decision-makers?" I address these questions through a case study of four cities in Los Angeles County: Long Beach, Los Angeles, Pasadena, and Pomona. This approach involved collecting and triangulating indepth interviews with AO leaders and city officials, document review of AO materials, and content analysis of each case city's Housing Element. In contrast to the literature on political opportunity, I found that AOs in open and closed opportunity contexts use both insider and outsider tactics as part of their advocacy for affordable housing. However, closed opportunity contexts were more likely to constrain AOs to reactive strategies, responding to existing opportunities, rather than influencing the agendas themselves.

This research draws from two social movement theories (political opportunity and resource mobilization theory) to frame the investigation and analysis. Social movement theories explain what factors influence organizations' tactical choices to bring about social change. Specifically, AOs mobilize to bring about social policies and oppose other groups' efforts (e.g., Not-In-MyBackyard groups [NIMBYs]). Research shows continued and long-standing opposition to affordable housing by many local governments and their residents (Nguyen, Basolo, and Tiwari 2012; Scheller and Yerena 2018). Because AOs serve a role in moving social policy forward, I use this theoretical framework to illuminate how they select tactics.

Political opportunity theory asserts that an $\mathrm{AO}$ will con- sider the degree of political freedom (i.e., free press, free speech, degree of openness or accessibility of the political system to collectivities' demands) that is available to them when selecting the tactics they use (Jepperson 1991; Meyer 2004; Snow, Soule, and Kriesi 2009b). Resource mobilization theory, however, claims the choice of tactics will depend on the resources available to an AO (Jenkins 1983; 
McCarthy and Zald 1977). Both theories explain some aspects of the tactics chosen by AOs in all four of the cases.

The contribution of this study to planning scholarship is to improve our understanding of urban governance in the development of local community housing plans and in the implementation of affordable housing policies. AOs are one of the "voices" that interact with planners in the affordable housing planning/policymaking process. Through this work, I join the conversation that emphasizes the importance of the "places" (as context) where planning decisions unfold (Beauregard 2015). Furthermore, this analysis matters to planners, because it provides a typology for us to assess and describe the place where our practice occurs and better understand the role this context plays in how others engage with the planning process. In addition, the case studies illustrate how AOs and planners can become partners in the pursuit of new or improved housing policies. This understanding will guide the future directions of planning literature on local policymaking theory and practice and become an essential component of what we teach future generations of planners. The current study adds to the literature on planning for and implementation of affordable housing policies and will offer a more nuanced understanding of the role of AOs in civic participation. For example, as planners better understand

AOs' role, they can better collaborate with them to promote the engagement of residents in the policymaking process. Planners have a responsibility to advance policy and can learn from these groups how they themselves can participate to influence policy.

\section{Theoretical Framework and Definition of Key Concepts}

In past studies that focused on different policy domains, AOs have been identified as actors that make claims to influence decision-makers (Andrews and Edwards 2004; Lucio and Ramirez de la Cruz 2012; Maclndoe and Whalen 2013; Nguyen, Basolo, and Tiwari 2012; Prakash and Gugerty 2010; Yerena 2015). For the purpose of this study, advocacy is any activity that an organization undertakes to influence policies. There is great latitude in this definition: it includes activities such as public demonstrations, providing comments on drafts of regulation, the filing of friend of the court briefs, and lobbying. ${ }^{2}$

The focus of this study is on the policy enactment process that is a target of the political influence these organizations wield. The groups that are the focus of this study, AOs, have access to the political structure and are constantly balancing between insider and outsider

\footnotetext{
${ }^{2}$ According to section 501(c)(3) of the Internal Revenue Service (IRS) Tax code, organizations registered under this tax-exempt status are allowed to engage in lobbying as long as it is not a "substantial part" of their activities. Section 501(c)(4) social welfare organizations and section 501(c)(6) trade associations may engage in lobbying activities without limits; in fact, that can sometimes be one of their main functions. As the "substantial part," definition is rather ambiguous, public charities that lobby should understand the monetary parameters for what constitutes "substantial." Political activity (i.e., campaigning in favor or against a candidate), however, is strictly prohibited
} 
tactics. Insider tactics are actions addressed directly at decision-makers (e.g., sitting on an advisory board) while outsider tactics involve sending a message to decision-makers indirectly (via public means).

AOs can seek impact at three levels: (1) toward a specific policy, (2) governance gains, and (3) civil society gains. Advocacy can thus achieve legal and procedural gains that benefit a group's constituency, can open up channels of communication so a group's constituency can take part in the decision-making process, and can build constituents' capacity to influence decisionmakers and create democratic and accountable structures.

In the current housing context, AOs serve as the main source of organized political pressure for decision-makers to address affordable housing issues. AOs mobilize public support for a variety of purposes related to their constituents' needs, including but not limited to (1) providing individuals or groups access to services, (2) protecting and expanding their constituents' rights, (3) calling for policy change, and (4) educating the broader public on their subject issue (Bratt 2012; Duncan 2004). To meet their purpose(s), some AOs, such as the National Low-Income Housing Coalition in Washington, D.C., conduct outreach to communities, while others, with a local focus, such as the Abode Communities of Los Angeles, develop and manage affordable housing while still others, such as the Right to Counsel New York City Coalition, campaign for specific tenants' rights issues. Silverman (2008) concurs that the creation and implementation of affordable housing policy has become less the result of intergovernmental work, and more the outcome of cooperation involving the government, AOs, and private organizations.

\section{AO Tactics}

Previous work distinguishes broadly between two types of $\mathrm{AO}$ tactics: insider and outsider tactics. Insider tactics encompass all concerted efforts undertaken by the AO to directly transmit their request(s) to decision-makers. Outsider tactics, however, rely on indirect pressure, such as influencing public opinion and mobilizing the general public in favor of the pol- icy change (Betzold 2013). Other terminology used to capture this dichotomy includes "access" and "voice" (Beyers 2004), or "direct" and "indirect" advocacy (Binderkrantz 2005, 2008). Insider tactics include direct interaction with individuals whose work purview includes housing policy, participating in the policy process, or delivering input to the Housing Department; outsider tactics, on the contrary, exert pressure through the masses, examples include media interviews, press releases, or demonstrations (Betzold 2013).

\section{Political Opportunity Theory}

This study is grounded on two theories, political opportunity theory and resource mobilization theory. Recent literature has examined the iterative relationship between collective actors and public policy (Amenta et al. 2012; Burstein and Linton 2002; Meyer 2009; Snow, Soule, and Kriesi 2009b), yet these studies do not deal with local policy issues. The focus on local policymaking (level at which most affordable housing decisions are made) allows for a better understanding of AOs' tactical decisions. 
This study focuses on the public policy creation and advocacy exchange that takes place within the system of institutionalized government-advocacy interactions. Currently the affordable housing policy arena, as structured by federal policy has created programs that have institutionalized the interplay between local government and some political actors. Therefore, this study focuses on the local context through the lens of collective action terminology. At the local level, we can understand what tactics AOs are choosing and why they use the insider/outsider tactics and interpret their political opportunity context as open/closed. Some argue that working within the system of institutionalized government-advocacy interactions limits AOs' effectiveness because it avoids disruptive tactics (Jepperson 1991; Meyer and Tarrow 1998). Yet, in this study, I find AOs understand these conventional ways of interacting with institutions and instead, leverage them to achieve policy change.

The relative openness of a political context is determined by the interplay of the political system, sociopolitical conditions, and AOs' interpretation of the situation. Open and closed political opportunity help us understand why AOs choose certain tactics as they respond to factors such as the climate of governmental responsiveness and the disposition of the chief executive (e.g., mayor), which facilitate or prevent citizen activity in search of political goals. According to this theory, the more open the political opportunities, the more likely AOs will use insider tactics.

Crucially, political opportunity theory focuses on the place where planning occurs, where AOs exist and interact with policymakers. In this study, I use Meyer's $(1993,455)$ definition of political opportunities as "the institutional and political factors that shape [an AOs'] options." The "options" this definition refers to include communication strategies, protest tactics, and network(s). Planners can benefit from AOs' analysis of the political context by cultivating relation- ships with these actors and becoming a part of their network. Through this shared understanding, planners can avoid missing opportunities to support AOs' policy work around afford- able housing and strategically continue the relationship at times when policy advocacy is less well poised to succeed. Ultimately, planners can serve as allies simply by helping AOs navigate the political structure within which local policy decisions are made.

AOs continuously interpret the opportunities presented within a given political context. The current housing crisis has increased the outrage of housing AOs' constituent base and highlighted the urgency for policy responses that ameliorate the negative effects this situation has on low-income households. Planners must also constantly interpret and respond to the political context in which they operate; there-fore, this analysis will prove useful to planning professionals and educators.

\section{Resource Mobilization Theory}

In contrast to political opportunity theory, resource mobilization theory attempts to move the analysis away from the social psychology of $A O$ actors to more easily observable AO characteristics to explain why they choose specific tactics (McAdam 1996). This theory claims that the persistence of collective action and the subsequent choice of tactics depend on the resources available to the AO (McCarthy and Zald 1977). Resources can be material, human, 
social-organizational, among others. This theory predicts that organizations with more resources will use a wider variety of tactics (insider and outsider) to attain influence, while groups with fewer resources will focus on fewer types.

Previous studies have focused on understanding how political opportunities (see Eisinger 1973) or resources (see Edwards and McCarthy 2009; McCarthy and Zald 2002) play a role in the development of collective actions and strategic choices. However, no research has looked into the effects of the interactions of both, specifically on the tactical choices organizations make. This study fills this gap by simultaneously analyzing aspects of both theories, theorizing that AOs undertake a two-step process wherein they assess the political opportunity and then take stock of the resources available to them to act accordingly. Doing so provides a more nuanced understanding of how resources interact with political opportunities. Analyzing either of these factors in isolation cannot fully explain how an AO makes its choices. Planners who are aware of, what I contend, is a two-step process can also act strategically to further a specific policy agenda.

\section{Analytical Strategy}

I conducted four case studies to contextualize tactics in sup- port of affordable housing in two pairs of cases with contrasting $A O$ resources in open and closed political opportunity cities. All cases share a housing environment with high housing costs and homelessness concerns making this work likely to be relevant in similar contexts. To complete the analysis, I conducted interviews (with AO leaders and city officials), reviewed documents, and completed content analysis. ${ }^{3}$ I triangulated interview responses with data gathered through document review of AO materials and content analysis of each city's Housing Element which is a section of a city's comprehensive plan that contains its vision and goals related to housing. The combination of data sources and methods enhanced the validity and reliability of the results generated by this study.

\section{Data and Measurement}

\section{Unit of Analysis}

The intent of the case studies was to describe and explain the tactics used by affordable housing $\mathrm{AOs}^{4}$ within a city and find out why they were chosen to influence policymakers. The study's unit of analysis is the city because this is the policy arena where land use decisions are made and afford- able housing policies are implemented. The AOs in each city provide

\footnotetext{
${ }^{3}$ I chose this research method because it meets three conditions: (1) the questions are interested in "operational links needing to be traced over time" (Yin 2009, 9), (2) I do not have con- trol over the actual behavioral events, and (3) the focus is on contemporary events. Furthermore, I conducted case studies, because this research framework allowed me to deal with a more compelling and wider variety of data (evidence) needed to answer these questions.

${ }^{4}$ I derived the organizations included in this study from the Urban Institute's National Center for Charitable Statistics' (NCCS) Business Master File for 2008. The NCCS uses the National Taxonomy for Exempt Entities (NTEE) classification to sort organizations based on their mission statement. All advocacy organizations (AOs) that took part in the study fall under the L-housing and shelter classification.
} 
illustrative scenarios as embedded units. These embedded units helped me focus the inquiry of the case studies (Carroll and Johnson 1990; Yin 2009).

I purposefully sampled cities that reflected varying AO resources and political opportunities (affordable housing support). To identify AO resources, I used secondary data obtained from the National Center for Charitable Statistics. These data included the number of AOs and their total assets and income, admittedly, a limited measure of AOs' resources, but one that is available and standardized across all eighty-eight cities in the county. To identify the range of affordable housing support levels, I completed a content analysis of each city's Housing Element coding for mentions of AOs within the document.

The cities I selected, Long Beach, Los Angeles, Pasadena, and Pomona, have varying levels of AO resources (see Table 1). The variation occurs along the independent variables: open or closed political opportunity and the amount of (aggregate AO per capita) resources in the city. One political variable to highlight across cases is the unconventional political opportunity index (Sharp 2005) which captures societal shifts such as women's participation in the labor force and the proportion of same-sex households.

Table 1. Important Characteristics of Case Study Cities.

\begin{tabular}{|c|c|c|c|c|}
\hline & Los Angeles & Long Beach & Pasadena & Pomona \\
\hline \multicolumn{5}{|l|}{ Theoretical Dimensions } \\
\hline AO Resources ${ }^{a}$ & $\begin{array}{l}\text { Low } \\
\$ 39.29\end{array}$ & $\begin{array}{c}\text { High } \\
\$ 554.26\end{array}$ & $\begin{array}{c}\text { High } \\
\$ 265.22\end{array}$ & $\begin{array}{l}\text { Low } \\
\$ 3.88\end{array}$ \\
\hline Political Opportunity ${ }^{b, c}$ & $\begin{array}{l}\text { Open } \\
80 \%\end{array}$ & $\begin{array}{c}\text { Closed } \\
100 \%\end{array}$ & $\begin{array}{l}\text { Open } \\
100 \%\end{array}$ & $\begin{array}{c}\text { Closed } \\
88 \%\end{array}$ \\
\hline \multicolumn{5}{|l|}{ Political Variables } \\
\hline $\begin{array}{l}\text { Local Government } \\
\text { Setup }\end{array}$ & $\begin{array}{l}\text { Mayor with } \\
\text { city council } \\
\text { and city } \\
\text { administrator } \\
\text { d }\end{array}$ & $\begin{array}{l}\text { Mayor with } \\
\text { city council } \\
\text { and city } \\
\text { manager }\end{array}$ & $\begin{array}{l}\text { Mayor with } \\
\text { city council } \\
\text { and city } \\
\text { manager f }\end{array}$ & $\begin{array}{l}\text { Mayor with } \\
\text { city council } \\
\text { and city } \\
\text { manager }\end{array}$ \\
\hline \# of council members & 9 & 15 & 7 & 7 \\
\hline $\begin{array}{l}\text { Unconventional } \\
\text { Political Culture Index h }\end{array}$ & 1.15 & 0.12 & 2.11 & -3.26 \\
\hline
\end{tabular}

Note: $A O=$ advocacy organization

a Determined the level of AO resources per city by using total per capita assets in each of the fourteen cities in Los Angeles County with a population more than one hundred thousand. I selected the cities that were at either extreme (high/low AO resources). As a reliability check, I also assessed the average value of assets owned by AOs in each city and the categorization for each city remained the same.

b determined Political Opportunity by completing a preliminary review of the Housing Element for a few cities in Los Angeles County that either had high or low AO resources (from step above). From this review, I identified four cities that put forth documents that came across as more open or closed opportunity policy contexts. I selected the two of the most open and two of the most closed political opportunity documents.

c During the interviews with organization leaders, I assessed how they interpreted the political opportunity context in their city. I list the percent agreement among organizations in parenthesis. If an organization stated something like city housing staff welcome and/or seek out our input on affordable housing matters, this counted as an open political opportunity. When organizations stated that they had to convince housing city staff to listen to them and/or that 
affordable housing was not seen as a priority within the city, then this response would count as being a closed political opportunity context. I triangulated these interview responses with the review of Housing Elements to validate my initial assessment.

h This measure captures societal shifts such as women's current social roles or nontraditional household arrangements that emerged over the past several decades. This index is constructed by the sum of the $z$ scores of: the percentage of households not married with children present, the percentage of women in the labor force, Same-sex partner households per thousand households, percentage of age more than twenty-five population with a BA or higher, the inverse of church adherents as percentage of population, and the percentage of working population in scientific, technical, professional, or education occupation categories (Baylor University 2010; Sharp 2005; U.S. Census Bureau 2010).

\section{Study Site and Case Selection}

This research includes four relatively large cities (more than 130,000 people) in Los Angeles County. The choice of one county ensures that cities are subject to the same state law (affordable housing state mandates) and state sponsored housing programs and that all cities participated in the same regional housing market and experienced the same level of intercity competition. ${ }^{5}$ Intercity competition incentivizes local decision-makers to adopt local policy in the city's economic interest and therefore favor developmental policies over redistributive policies (such as those related to afford- able housing; Basolo 1997; Yerena 2015). Los Angeles County is a highly competitive housing market (intercity competition is 1.1 standard deviations above the national mean). Indeed, according to the HUD's (2012) Point-in- Time count, Los Angeles County has the second largest population of homeless individuals in the country (behind New York) and the majority of its renter (56.5\%) and owner (55.1\%) households are housing cost burdened (U.S. Census Bureau 2010).

Moreover, the county is racially and ethnically diverse, featuring 48 percent Hispanic or Latino, 14 percent Asian, and 9 percent Black/African American residents thus epitomizing the ethnic and racial diversity that will take place in other many other regions across the United States in the near future (Craig, Rucker, and Richeson 2018). Housing policy-making has a long racialized history (Díaz McConnell 2017; Hirsch 2000), and while the interplay of housing policy and racial and ethnic composition is not the focus of this analysis, the latter serves as part of the sociopolitical context in which $\mathrm{AO}$ actions and planning take place. Table 2 presents a summary of contextual variables for all case study cities in relation to the county to provide a snapshot of the urgency of the housing crisis in this region and depict what makes each of these communities unique. In particular, except for Pasadena, the cities are similarly diverse in terms of race and income. Pomona is noticeably less wealthy and of course, Los Angeles city has a drastically higher population

\footnotetext{
${ }^{5}$ Per previous work (Basolo and Lowery 2010), I operationalized intercity competition as the sum of all incorporated cities plus counties in a city's metropolitan statistical area using data from the U.S. Census Bureau (2010).
} 
Table 2. Study Sites' and County's Contextual Variables

\begin{tabular}{|c|c|c|c|c|c|}
\hline Variable & $\begin{array}{l}\text { Long } \\
\text { Beach }\end{array}$ & $\begin{array}{c}\text { Los } \\
\text { Angeles }\end{array}$ & Pasadena & Pomona & $\begin{array}{l}\text { Los Angeles } \\
\text { County }\end{array}$ \\
\hline Population & 462,257 & $3,792,621$ & 137,122 & 149,058 & $9,818,605$ \\
\hline Population change $^{a}$ & $0.10 \%$ & $2.63 \%$ & $2.38 \%$ & $-1.26 \%$ & $3.15 \%$ \\
\hline Residents 65 years + & $9.27 \%$ & $10.46 \%$ & $13.54 \%$ & $7.63 \%$ & $10.85 \%$ \\
\hline \multicolumn{6}{|l|}{ Racial/Ethnic Composition } \\
\hline White (Not Hispanic) & $29.36 \%$ & $28.66 \%$ & $38.75 \%$ & $12.53 \%$ & $27.8 \%$ \\
\hline Black/African American & $13.54 \%$ & $9.63 \%$ & $10.68 \%$ & $7.33 \%$ & $8.73 \%$ \\
\hline Asian & $12.87 \%$ & $11.26 \%$ & $14.29 \%$ & $8.51 \%$ & $13.72 \%$ \\
\hline $\begin{array}{l}\text { Native Hawaiian and other } \\
\text { Pacific Islander }\end{array}$ & $1.14 \%$ & $0.15 \%$ & $0.10 \%$ & $0.19 \%$ & $0.27 \%$ \\
\hline $\begin{array}{l}\text { American Indian/Alaska } \\
\text { Native }\end{array}$ & $0.75 \%$ & $0.74 \%$ & $0.60 \%$ & $1.18 \%$ & $0.74 \%$ \\
\hline Some other race & $20.32 \%$ & $23.81 \%$ & $13.62 \%$ & $30.30 \%$ & $21.8 \%$ \\
\hline Two or more races & $5.29 \%$ & $4.63 \%$ & $4.88 \%$ & $4.47 \%$ & $4.5 \%$ \\
\hline Hispanic or Latinob & $40.76 \%$ & $48.48 \%$ & $33.67 \%$ & $70.53 \%$ & $47.7 \%$ \\
\hline Average household size ${ }^{c}$ & 2.7 & 2.8 & 2.4 & 3.7 & 2.9 \\
\hline Median household income & $\$ 52,711$ & $\$ 46,148$ & $\$ 65,422$ & $\$ 50,497$ & $\$ 55,476$ \\
\hline Median home price & $\$ 395,000$ & $\$ 438,300$ & $\$ 601,000$ & $\$ 259,900$ & $\$ 429,500$ \\
\hline Overall vacancy rate & $8.5 \%$ & $7.2 \%$ & $7.9 \%$ & $7.5 \%$ & $6.5 \%$ \\
\hline Homeowner Vacancy rate & $2.0 \%$ & $2.10 \%$ & $2.30 \%$ & $2.0 \%$ & $1.7 \%$ \\
\hline Rental Vacancy rate & $5.9 \%$ & $6.10 \%$ & $6.60 \%$ & $5.9 \%$ & $5.8 \%$ \\
\hline Unemployment & $10.1 \%$ & $9.1 \%$ & $8.0 \%$ & $10.7 \%$ & $8.7 \%$ \\
\hline Percentage below poverty & $20.2 \%$ & $21.2 \%$ & $12.9 \%$ & $20.4 \%$ & $17.1 \%$ \\
\hline Homeless count $^{d}$ & 3,909 & 25,771 & 1,137 & 790 & 38,289 \\
\hline
\end{tabular}

Sources: U.S. Census, 2000 and 2010

American Community Survey 5-year estimates, 2010

U.S. Housing and Urban Development (HUD) Point-in-Time (PIT) homeless count, 2010

City of Pomona State of Homelessness, 2013

Los Angeles Homeless Services Authority Greater Los Angeles Count Report, 2011

Notes:

${ }^{a}$ Comparing 2000 and 2010 U.S. Census data

${ }^{b}$ As reported by the U.S. Census, the Hispanic or Latino category overlaps with other race categories, therefore the Racial/Ethnic

Composition percentages do not add to 100 for any given city.

c Persons per household

${ }^{d}$ HUD reports Point-in-time (PIT) homeless counts per Continuum of Care (CoC) area. CoCs are sometimes cities, other times counties, and sometimes a combination of the two. For example: Los Angeles County and Los Angeles City are reported in the same CoC. I therefore used the City of Pomona's PIT count as reported by the city in 2009 (the City of Pomona's report contains data for 2009 and 2011, but not for 2010). Similarly, for the City of Los Angles, I used the city's Homeless Services Authority report with data for 2009 (the report contains data for 2009 and 2011, but not for 2010). Long Beach and Pasadena have their own CoC. 


\section{Data Collection Procedures}

I completed data collection over two years from October 2012 to November 2014, using three

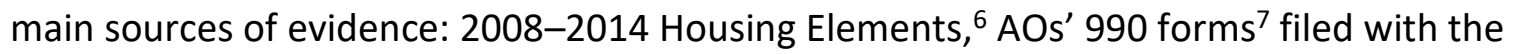
Internal Revenue Service for fiscal year 2011, and interviews. These included the most recently published documents at the time of fieldwork.

\section{Study Participants}

I reached out to the cities' housing departments and requested to speak to local housing staff and officials in each case city. After explaining the purpose of the study and providing an example of the types of questions I would be asking, housing department heads (or their equivalent) in three cities agreed to participate. The city of Long Beach (firmly) declined to participate in the study without explanation.

Twenty-four AOs agreed to participate in the study. I spoke to nine AOs from Los Angeles, six AOs based in Long Beach, five in Pasadena, and four in Pomona. Participants agreed to share their organization's strategic choices and assessment of local decision-makers' disposition toward affordable housing. I agreed to keep participants and their organizational affiliations anonymous. The AOs that participated in the study included long-term advocacy groups, homeless service providers, and organizations that provide legal representation on housing issues. The individuals that represented these organizations ranged from grassroots organizers and lawyers to housing advocates. All participants hold a decision-making role in tactical choices within their organizations.

\section{Data Coding for Analysis}

The data analysis tasks included: (1) a content analysis of the Housing Elements to categorize each city's political opportunity context as open or closed; (2) a detailed review of organization's 990 forms to take stock of the resources, other than assets, AOs had at their disposal; and (3) coding of semi-structured interviews with local housing staff and officials in each case city and with $\mathrm{AO}$ leaders across case study cities, to triangulate among participants and with the open- closed assessment of each city.

\footnotetext{
${ }^{6}$ In the state of California, all cities must draft a plan to comply with AB 2853, the law that requires cities to draft and update (every eight years) a Housing Element plan that identifies existing housing needs of all income levels, establishes goals, policies, quantified objectives, and schedules programs for the preservation, improvement, and development of housing (Baer 1988).

${ }^{7}$ Form 990 is an annual information return that most organizations exempt from income tax under section 501(a), and certain political organizations and nonexempt charitable trusts are required to file with the IRS by. Parts I through XII of the form must be completed by all filing organizations and require reporting on the organization's exempt and other activities, finances, governance, compliance with certain federal tax filings and requirements, and compensation paid to certain per-sons. These groups are all tax exempt under Internal Revenue Code section 501(c), 527, or 4947(a)(1) (IRS, n.d.).
} 
I started by completing a content analysis of the Housing Elements in each case study city to determine the level of engagement and recognition these official documents expressed toward local AOs. I coded for (1) measures taken by the city to promote the production/availability of affordable housing, and (2) mention of the work of AOs in the drafting of documents or work initiatives.

Second, I completed open coding of interview transcripts searching for AO leaders' perception of the openness of the system in which they were working. This coding focused on the way AO representatives described their interactions with city officials around issues of affordable housing. This served as a reliability check for what I found in the Housing Elements. I also coded interviews for the tactics AO leaders and city officials mentioned. For sample quotes, see Table 3. I used techniques from Glaser's (1965) constant comparative method to compare the properties of each open code to each other and to collapse and expand codes based on the initial research question and the themes identified during content analysis. The resulting collapsed and expanded codes were used to con- duct a focused coding of interviews. All sources of data were analyzed iteratively following the recommendations of Yin (2009).

\section{Table 3. Operationalization of Open vs. Closed Political Opportunity}

\begin{tabular}{|c|c|c|}
\hline $\begin{array}{l}\text { Political } \\
\text { Opportunity }\end{array}$ & Excerpts from Housing Elements ${ }^{a}$ & Quotes from AO leaders ${ }^{b}$ \\
\hline \multirow[t]{3}{*}{ Open } & $\begin{array}{l}\text { "...work with dozens of nonprofit and } \\
\text { for-profit organizations to build } \\
\text { (continued on next page...) } \\
\text { affordable housing, rehabilitate and } \\
\text { preserve housing, and provide an } \\
\text { extensive menu of supportive } \\
\text { housing...." - Pasadena Housing } \\
\text { Element }\end{array}$ & $\begin{array}{l}\text { "The city (Pasadena) is more than any other } \\
\text { city in the San Gabriel Valley, committed to } \\
\text { ending homelessness and also doing } \\
\text { something about affordable housing... Mx. Y, } \\
\text { who is the Head of the Department of } \\
\text { Housing at this point... is working very hard } \\
\text { to make sure we end homelessness in the } \\
\text { next ten years. The city council, generally } \\
\text { speaking, will fund affordable housing." - } \\
\text { Pasadena AO }\end{array}$ \\
\hline & $\begin{array}{l}\text { "In drafting the Housing Element,... [the } \\
\text { City] interviewed more than } 30 \\
\text { nonprofit organizations, housing, and } \\
\text { planning staff; community advocates; } \\
\text { developers; City Council; residents; and } \\
\text { other stakeholders. This process } \\
\text { concluded in March 2007." } \\
\text { - Pasadena Housing Element }\end{array}$ & \\
\hline & $\begin{array}{l}\text { "Contact nonprofit housing } \\
\text { organizations by the end of } 2009 \text { to } \\
\text { solicit interest in preserving at-risk }\end{array}$ & \\
\hline
\end{tabular}




\begin{tabular}{|l|l|l|}
\hline & $\begin{array}{l}\text { housing projects."-Los Angeles Housing } \\
\text { Element }\end{array}$ & \\
\hline Closed & $\begin{array}{l}\text { "[provide] the addresses and building } \\
\text { management contact information of } \\
\text { affordable housing units... to community } \\
\text { and housing organizations." - Pomona } \\
\text { Housing Element }\end{array}$ & $\begin{array}{l}\text { "[the] mayor we have is very powerful and } \\
\text { very opposed to affordable housing... There } \\
\text { is a very strong, dogmatic opposition to } \\
\text { affordable housing." - Long Beach AO }\end{array}$ \\
\hline
\end{tabular}

${ }^{a}$ Housing Elements excerpts were used during the study's case selection and data analysis.

${ }^{b}$ Quotes from AO leaders were triangulated with Housing Element excerpts to assess each city's political opportunity categorization.

\section{Findings}

The research questions that guided this analysis were "What type of tactics do AOs use to influence city affordable housing policymaking?" and "Why do AOs in some cities favor certain tactics over others?" As AOs decide how they actualize their goals for affordable housing, both political opportunities and resources are considered in what I term a two-step process. Given the political nature of affordable housing issues, every $A O$ in these four cities first reads the political context then takes stock of its resources. Resources thus present opportunities or constraints for the range of tactics the AO can employ. Neither of these two factors fully determines an AO's choice of insider versus outsider tactics.

Through this study, I integrated both political opportunity and resource mobilization frameworks to understand $\mathrm{AO}$ actions. I present the findings organized by city to clearly depict the interplay between the two frameworks in each case. In Table 4, I summarize the instances each type of tactic was used by high-/low-resource AOs according to each city's political opportunity context.

Table 4. Coding Percentage of Insider and Outsider Tactics by Political Opportunity and AO Resources

\begin{tabular}{|l|c|c|c|c|c|c|c|c|}
\hline & \multicolumn{4}{|c|}{ Closed Political Opportunities } & \multicolumn{3}{c|}{ Open Political Opportunities } \\
\hline & \multicolumn{2}{|c|}{ Long Beach } & \multicolumn{2}{c|}{ Pomona } & \multicolumn{2}{c|}{ Los Angeles } & \multicolumn{2}{c|}{ Pasadena } \\
\hline AO Resources & High & Low & High & Low & High & Low & High & Low \\
\hline $\begin{array}{l}\text { Insider } \\
\text { Tactics }\end{array}$ & $40 \%$ & $67 \%$ & $49 \%$ & $64 \%$ & $50 \%$ & $65 \%$ & $43 \%$ & $55 \%$ \\
\hline $\begin{array}{l}\text { Outsider } \\
\text { Tactics }\end{array}$ & $60 \%$ & $33 \%$ & $51 \%$ & $36 \%$ & $50 \%$ & $35 \%$ & $57 \%$ & $45 \%$ \\
\hline
\end{tabular}

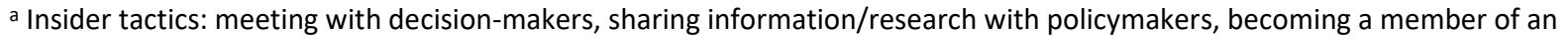
advisory group, participating in policy debates, delivering input to Housing Department, and drafting of legal text.

b Outsider tactics: hosting a side event/conference, sharing information with the public, leading a letter writing campaign, granting (or arranging) a media interview, coordinating a press release, organizing a demonstration, holding a press conference, and sponsoring a documentary/film. 
Long Beach

At the time of this study, the political opportunity context in Long Beach was unanimously interpreted by AOs as a closed political context. As an AO leader shared,

The folks that are on "the inside," on the government side of stuff, publicly are rarely helpful. Privately, some are at least helpful in terms of giving you the lay of the land, but most, in my experience here, are not helpful. Affordable housing is a lightning rod for anybody on the government/city side. There aren't many people who will stand up for the issue because they are worried about their jobs. I think there are some folks who have been downright oppositional to the point of being illegal... .

Another way in which AOs conveyed their interpretation was by comparing it to a previous time when the context was more open and explaining how this political shift changed the organization's tactical choices. For example, this AO leader from a high-resource AO in Long Beach describes the tactics the organization employed to effect change in the implementation of a policy that was already in place:

At least a decade ago, instead of filing a lawsuit or trying to [draft] a law, I met with the director for the program and explained what the Federal and State requirements were... I just explained it to them, I did [direct] advocacy, and got them to understand the importance of the changes so that their programs were in compliance... I was able to convince them [local officials] that they needed to change their procedures, and I didn't have to confront them with a lawsuit or write legislation, it was a matter of educating, meeting, advocating, and showing that I can be a helpful partner in moving the work forward.

More recently, under a new mayor, the same AO used mainly outsider tactics. The AO leader depicted its organization's tactical choice as follows:

The campaign included lots of media work, press conferences, op-eds, meetings with council members, meetings with staff, testifying at hearings and study sessions, educating residents, working on other AOs' steering committees, working with the State Department of Housing and Community Development and using them as leverage to get the city to make revisions. Also, working with some outside experts who provided some support to our organization.

This finding confirms previous research that links group access and choice of tactics to changing individuals in power (Jenkins 1983). AOs engage in a variety of tactics over time and shift their tactical choices (open/closed) in response to changing political opportunities. This process of recalibration and adaptation confirms previous results (Yerena 2015) that suggest that the age (political maturity and acumen) of the AOs operating in the city is associated with improved affordable housing policy outcomes. 
The closed political opportunity AOs described coincided with my coding of the City of Long Beach's 2008-2014 Housing Element Plan. This planning document contains no indication of the entities or organizations (governmental or nongovernmental) that are expected to undertake the policies to achieve the plan's goals. Thus, the plan proceeds without any inherent accountability or flowchart of how the process will move forward with its goals. The plan does not make any concerted call to action to its readers or specify how/if local organizations will be involved. Finally, the plan is missing a "human element," to connect the plan's goals to the real-world needs of community members.

AOs working in this closed political opportunity context went to great lengths to make the smallest amount of difference in the wording of plans. Another Long Beach AO leader from a low-resource $A O$ recounted a recent experience:

We were trying to get the city to make some commitment to consider inclusionary housing in the 2014 housing element. [W] wo worked with a wellknown economist [to complete] an economic analysis... Our "ask" was strong; to adopt an inclusionary housing ordinance by 2014 with 10\% very lowincome units. When it became clear we didn't have support for that, it weakened into: why don't you at least consider it in 2014? Based on the pushback we were getting from the city attorney, city council, and city staff, we changed it again and by the time we went to the final hearing, we were just saying, include language that in 2014 the city will consider inclusionary housing. [W] just wanted a "launch pad" of language so we could bring it up the following element, but ultimately, staff and the city attorney said some really damaging things on the record and we weren't able to include any [inclusionary housing] language at all.

In contrast, the actions high-resource AOs undertake include a wider range of insider and outsider tactics. For example, a high-resource $A O$ explained the resources and tactics they mobilized in a recent campaign as follows:

[F]und raising to get the study/economic analysis, our professional network, we met with council members, we testified at hearings. We created fact sheets for the community and elected officials which summarize why this is important, what other cities have done. We worked with the media, and I worked with my community allies.

Here is another example depicting the range of insider and outsider strategies from a similarly well-resourced AO:

[W] move the issue forward in a public way... We've utilized dozens of strategies, we've done op-eds, we've done endorsement letters and pledges, we created a documentary and we did a film screening across town, we hosted a jobs and housing panel with experts from across the county, we do legislative visits, we go to the city meetings, we have community forums... 
As noted in Table 4, political opportunity theory is inconclusive in predicting the type of tactics; instead, it is the AO's resources that allow it to broaden its range of tactics toward more outsider tactics. However, this theory does explain the approach (reactive or proactive) AOs have toward advocacy. AOs in Long Beach (politically closed) exemplify reactive policy advocacy, whereby organizations' issues and tactical choices are impacted by policymakers' reluctance to move forward on (or even discuss) certain issues. As one AO leader explained it:

Our campaigns are defined by the opportunities we identify, a lot of our campaigns have been reactive because, they arise from something the city is moving forward with and we take the opportunity to try to re-shape it [the policy or program].

The political context in Long Beach was poignantly summarized as follows:

[The] mayor we have is very powerful and very opposed to affordable housing. He says we have enough and we don't have to do more... [C]ity staff in Long Beach are a huge problem around affordable housing. They honestly think that we have enough money and they don't support inclusionary housing or linkage fees... even though we don't have any permanent dedicated local sources and redevelopment money has dried up.

\section{Los Angeles}

The overwhelming majority (80\%) of the AOs I interviewed whose policy advocacy is based in Los Angeles agreed that the city was experiencing a time of open political opportunity for affordable housing. There was only one AO leader that had misgivings about characterizing the city's political opportunity as fully open. Their hesitation was due to a recent experience with local groups (e.g., Building Industry Association and local neighborhood councils) that mobilized against an affordable housing policy they advocated for.

The mainly open political context was further evidenced through the city of Loa Angeles's Housing Element (2008). For example, the document announced the city would pursue funding for community organizations and advocates to conduct outreach and disseminate information regarding housing approaches. The plan also stated its goal to maintain and increase the supply of housing, especially affordable housing and to preserve existing units and provide equal access to housing opportunities by specifically listing programs that could mitigate potential constraints to meet these goals. The document did an excellent job of clearly stating how actors within and beyond city government would be involved in achieving these goals. All of the plan's programs had objectives, a deadline, targeted groups, geographic areas, and funding source(s).

Furthermore, the rationale behind the recommended courses of action was effectively presented by providing facts from research conducted prior to drafting the plan, cur-rent and projected demographic data, and input from AOs and residents. Based on the findings generated by these three sources, the plan recommended higher density for all new housing developments. The plan further defined the goals of its programs by setting up intermediate goals and suggesting alternate courses of action. The plan offered solutions and actions 
(policies, programs) to affordable housing issues and gave explanations and justifications (i.e., data, trends, graphs) for each course of action. By providing reasonable justifications, the plan sought to support and motivate people to act.

In this political context, AOs leverage the role local officials and city staff play in advancing affordable housing policies and improving housing programs. Both high- and low-resource AOs cited meeting and interacting with policy- makers and city staff (insider tactics) as part of their policy advocacy work. This finding, that government support influences the choice of AO strategies, is consistent with Meyer and Minkoff's (2004) study on what accounts for successful policy outcomes through collective action.

An AO leader in Los Angeles shared specific examples of the open political opportunity context around housing policies:

[For] the mixed-income ordinance in the city of LA there were certainly two or three [LA City council members] that were really solidly on board and would talk about it, advocate for it, and make appearances in the newspaper in favor it and things like that. Or with the density bonus, same thing. These were all city council members and then the mayor's office joined in, the staffs were great, they were just as close with us as a team.

AOs explained that the willingness of the corresponding jurisdictions to consider affordable housing policy improved the outcome of their advocacy effort. For example, a high-resource AO recalled a time when its leadership identified a problematic housing policy. The AO dedicated a committee, co-director, and lead housing organizer to head a campaign that included coordinating petitions, delegation visits, public testimony and meetings with landlords (insider and outsider tactics). The AO met and worked with the city's housing department, eventually leading the policy change.

As one high-resource AO leader summarized:

Really it is about trying to wield influence in the right way. We participate in education campaigns, letter writing, lobbying, meetings... it's bits and pieces of all of them...

Yet, AOs in Los Angeles, at times, still failed to achieve policy change. The difference lies in that these "failures" cannot be traced back to a lack of collaboration/support from policymakers. Instead, they are due to the influence of oppositional interest groups and the AO's overestimation of the sociopolitical context as open ("systematic optimistic bias"; Gamson and Meyer 1996, 289). One low-resource AO in Los Angeles described using both insider and outsider tactics to no avail in the following situation:

We didn't get a mixed income inclusionary ordinance adopted... We invested many resources... we met with all councilmembers. When there was one councilmember we couldn't get, we organized a canvasing operation and collected however many hundred cards from that district in support and 
delivered them to the councilmember's office... We attribute the failure to the opposition, that is the market rate developers, the neighborhood councils, and statewide opposition... In the end, it was the court case, the Building Industry Association's fight against inclusionary housing that has been around forever that prevented the ordinance from being adopted.

A Los Angeles housing staff member corroborated this account, recalling how the pressure from an opposing group overturned the decision, despite the varied tactics groups employed and the council's willingness to enact the proposed policy change. Not surprisingly, both high- and lowresource AOs in this context used both tactic types. Yet, the political support was insufficient to overcome the opposing group's influence.

Low-resource AOs in Los Angeles found ways to leverage their financial resources by partnering and building coalitions to then use insider tactics. As the policy director of this (low-resource) AO stated,

Our organization builds broad coalitions with other types of organizations like churches, foundations and community, labor, environmental, and health groups. Within the coalition, we say, whom can we get in this district? Who are we having trouble with as an elected official? Then we are referred to a specific person or organization that has a good relationship with that elected official and then you go and meet with them and see what they are willing to do.

Overall, AOs in Los Angeles (politically open) exemplified a proactive policy advocacy approach, whereby the organizations bring issues and potential solutions to the attention of policymakers.

\section{Pasadena}

At the time of this study, Pasadena's affordable housing policy environment was also an open opportunity context. Pasadena AOs were comfortable working with local policy-makers and trusted that they were "working together to improve affordable housing in our community" as one AO leader stated. Another AO leader concurred by explaining,

The city's housing vision is very powerful: To provide a decent home that every citizen in our city can afford. We see ourselves as supporting the city's housing vision and going beyond that at times. For every issue we've had a different ally. Sometimes it's the city staff and housing department, other times it's just one of the two, but we always have someone in our corner... Years ago, we promoted separating the planning and housing staff and creating a separate department for housing and they [city council] actually listened to us.

The open political opportunity context in Pasadena was evident in its Housing Element. The document went into detail about how several housing committees encouraged local residents (constituents) to contribute ideas and housing concerns for this plan. The plan identified the city's Housing Affordability Task Force (HATF) “to examine the City's housing needs, review 
current housing programs, and pro- pose new initiatives to improve housing opportunities" (City of Pasadena 2008, 11). This group consists of an exceptionally broad range of participants, including residents and local community groups. The plan also described the public work- shops the city held in the months prior to the drafting and adoption of the plan. These workshops further involved the public in the process by collecting additional housing needs and concerns. The input from these workshops was later incorporated into the policies and its programs. The vision set forth by the 2008-2014 Housing Element (City of Pasadena 2008) plan expresses residents' right to safe and affordable housing and elaborates on the city's desire to foster a socially and economically diverse community. The plan presented several policy changes aimed directly at improving the provision and protection of afford- able housing. For example, "although few condominium conversions were taking place in 2004, the City Council felt that additional protections were needed to address the dis- placement of residents when condominium conversions would occur" (City of Pasadena 2008, 45). To serve this aim, the City Council planned to enact a range of regulatory measures widely modeled after state law.

A high-resource $A O$ in Pasadena reported their tactics to promote affordable housing policies as follows:

[Using] my background in housing and law, we protest, we appeal to city councilmembers, we work to contact people, we [host] educational forums, we write op-eds and other write-ups in the paper saying with things like "we will continue to do this," we also meet with each one of the city council and planning department people... We provide training, not only to our own membership, but [to] low-income tenants to speak about what they wanted out of the process and out of the Housing Element. It wasn't just the usual suspects that were coming to City Hall and [speaking] before the Planning Commission.

AOs in Pasadena (open political opportunity), tended to identify issues, put them on the city's agenda and propose potential solutions. Below is a quote from a low-resource AO leader that was brought up by several interviewees:

We are now in the midst of a campaign to get an affordable housing commission for the city of Pasadena because we found that without a commission, although people acknowledge that affordable housing needs exist, there is no one group within the city that is really honed in on the question of how to preserve and produce affordable housing on a routine basis.

The city staff member I spoke to concurred with the AOs' accounts and provided examples of the insider and outsider tactics the groups used to create this commission. They further explained,

...[T]he advocacy groups are proposing a housing commission. They've been going before city council during the public comment session, going around talking to groups and individuals to try to get them to send in letters in 
support of it, talking to the League of Voters, talking to neighborhood councils and meeting with council members.

This example further illustrates how open political opportunity contexts are conducive to proactive policy advocacy approaches by local AOs.

\section{Pomona}

Pomona, like Long Beach, is a city with closed political opportunities; however, in Pomona, AOs have lower levels of resources, thus relying more on insider tactics. As a (low-resource) AO executive director explained,

$[H]$ ere in the Valley, policymakers and residents are very resistant to affordable housing structures being put up in their communities. So when we see that kind of resistance, we attend the community meetings to help residents and policymakers understand the value of affordable housing and also try to explain the differences between the myths of affordable housing and the realities of affordable housing.

Another AO further confirmed the closed political context by contrasting it with a nearby city's:

About two years ago [a resident] became very adamant about El Monte supporting the construction of an affordable housing project. With their activity and support, we worked with the city... So we had meetings at town hall where we brought in developers and basically educated everyone, as a result... city council approved the development of the project. It was then financed and built, and they just had the grand opening about a month ago. This would never have happened in our city; we just couldn't get that kind of support or interest in our city.

The review of Pomona's 2008 Housing Element supports the view that Pomona is a closed political opportunity context. The document's "purpose" (as stated throughout the document) was to satisfy California state law requirements. Furthermore, the plan did not describe any past or future efforts made to elicit or obtain input from local organizations or residents. Pomona's plan kept the same goals from the previous plan with minor changes to a few of the policies even though, on several occasions, the plan identifies problems that are becoming more pervasive throughout the city (e.g., over-crowding). In summary, the document did not present compelling arguments in support of affordable housing and fails to describe a sense of urgency to address its affordability issues.

AOs in Pomona were more likely to employ insider tac- tics in their policy advocacy. Below is a (low-resource) AO leader's description of the type of tactics they used to influence policymakers in Pomona:

[W] hen things come up, what we have been trying to do is trying to meet with the staff, if it is planning staff that is promoting it (affordable housing issue), then we are meeting with them, if it is the housing staff, we are meeting with 
them. And then follow that progression, because a lot of things wind up before the planning commissioners and city council. We try to meet with them individually and then as a body.

However, a (high-resource) AO leader recalled their tactical choices as insider and outsider, We have gone to council meetings to speak on behalf of affordable housing developments, to talk on behalf of [housing] policy changes... we help promote and identify and educate our members about different pieces of [housing] legislation... [We lead] education campaigns, letter writing, contacting elected officials, participate in conferences, bargain with elected officials in local jurisdictions... We have a yearly summit in which [we host] presentations about legislative options and opportunities, so we facilitate conversations and get information to the partners and policymakers, to try to help everybody understand things.

This same AO further described their most widely used (insider) tactic, providing information to policymakers. The AO leader shared that when a decision is being discussed,

We provide research for them [policymakers], we provide the ability to bring to the table the pieces that maybe are out there, that they are not aware of, or don't have time to research.

Similarly, other low-resource AOs, rely on both insider and outsider tactics, as this AO leader shared:

I think [we advocate] by telling specific stories, that's when we saw planning commissioners starting to change their minds, they started softening up after we spoke.... we started to make it personal... but then when it went to the city council, it was a different issue. [We also work] to expand the base of knowledge for those people who may not need affordable housing now, but as they get older, they need to share housing, or they have need for their parents. All our campaigns have an educational element, not only for the people we are trying to influence, but also the community in which we live.

Yet, all the examples shared evidenced a reactive approach to their advocacy work, whether this meant they shared research, show up to speak in support/against policies, or educate the community.

All four cases show the two-step process operates in the background of AOs' practice. AOs in these four cities interpreted the context (first) and proceeded based on this under- standing to decide which type of tactics and resources from their wheelhouse were appropriate for the situation. The political context, on the contrary, influenced whether they responded to a predetermined policy agenda (were reactive) or set the agenda themselves (were proactive). 


\section{Conclusion}

While there is a pattern of high-resource AOs in both open and closed opportunity contexts favoring outsider tactics and vice versa, all AOs interviewed used both types of tactics. When selecting their tactical approach, AOs in these four cases went through a two-step process, assessing the political context then taking stock of their resources/tactics. This process resulted in their range of tactics more likely being influenced by the resources the organization possessed than by the political context in which the group acted. This finding contradicts the political opportunity theory's prediction that AOs in closed political contexts are likely to favor the use of outsider tactics.

AOs in the two closed political opportunity contexts were likely to be reactive to policymakers' affordable housing agenda by focusing their efforts on counteracting their decisions. In contrast, AOs in the two open political opportunity contexts were proactive in their affordable housing policy efforts. AOs in these settings looked for new policies that would promote the preservation and creation of affordable housing and openly discussed them with policymakers. Through this process, AOs were able to build long-standing relationships with decision-makers, which can bring about innovative housing policies.

The AOs in the four cases were nimble enough to pursue both insider and outsider tactical approaches unlike previous work would have predicted (Barakso 2004; Jenkins and Perrow 1977). These groups' "tactical repertoires" (Snow, Soule, and Kriesi 2009a) were varied and did not prevent the AOs from pursuing a different tactic based solely on their reading of the political context. Furthermore, the vast majority of organizations studied were interested in building coalitions and saw them as a strategic choice regardless of the potential dilution of their identity.

Future research can expand on the findings of this work by conducting longitudinal studies that will allow for a better appreciation in the shifting of tactical choices according to political opportunities as well as resource availability. For affordable housing, a useful timeframe would follow the drafting of Housing Element plans: in California this currently happens every eight years. Another valuable inquiry would look into the types of resources an AO has and whether these resources make a difference on tactic choices. Future research can also look at how AOs perceive the relative strengths and weaknesses of specific tactics or how the diversity of tactics interacts to help the organization bring about policy change.

\section{Implications}

The results presented in this work have several planning and policy implications. First, planning for and delivering affordable housing in communities involves a process with multiple actors who are negotiating a complex political environment. Planners should remember that the political opportunity structures shape the outcomes of policies and plans. Second, as professionals that work closely with decision-makers, planners are well positioned within communities to encourage dialogues on affordable housing issues. Planners' role includes creating networks, bringing people into the room, and building avenues for relationships to 
develop. The relationships built between AOs and decision-makers can support AOs taking on a more proactive role in shaping the local housing policy agenda. Fostering these relationships can happen as a part of drafting planning documents (e.g., zoning changes) and by getting to know and networking with local AOs. Most importantly, in closed political systems, planners should foster relationships with AOs to indicate their willingness to advocate for the advocates and bring in AOs to educate policymakers on housing issues. As members of city staff, planners work in support of city council's interests and if affordable housing policy is not (or low) on their priority list, planners can call on AOs use their tac- tics to ensure housing makes its way up policymakers' priority list.

Finally, while financial resources play an important role in AO operations, other types of resources such as personal contacts are crucial in supporting AO's policy advocacy. Planners can educate newer AOs on the lay of the land and connect them to decision-makers. The sustained participation of AOs in affordable housing service delivery also provides opportunities to improve interactions between the residents in need of affordable housing and local decisionmakers. These interactions may lead AOs to support local officials in the pursuit of state and federal legislation for affordable housing.

To be sure, the solution to the current affordable housing crisis does not rest solely on the shoulders of affordable housing AOs, yet their continuous work and understanding of the housing issues can play a large role in cities' policy and implementation responses to this pervasive issue. AOs provide local policymakers with on-the-ground, up-to-date information and can mobilize their constituent base in support of innovative solutions. Whether the solution involves tenant protections, reducing the amount of single-family zoning, or changing state regulation, AOs are always thinking about housing policy solutions.

\section{References}

Amenta, Edwin, Beth G. Gardner, Amber C. Tierney, Anaid Yerena, and Thomas A. Elliott. 2012. "A Story-Centered Approach to the Newspaper Coverage of High-Profile SMOs." Research in Social Movements, Conflicts and Change 33:83-107.

Andrews, Kenneth T., and Bob Edwards. 2004. "Advocacy Organizations in the U.S. Political Process." Annual Review of Sociology 30 (1): 479-506.

Baer, William C. 1988. "California's Housing Element: A Backdoor Approach to Metropolitan Governance and Regional Planning." Town Planning Review 59 (3): 263-76.

Barakso, Maryann. 2004. Governing NOW: Grassroots Activism in the National Organization for Women. Ithaca: Cornell University Press.

Basolo, Victoria. 1997. "Housing Policy in the Local Political Economy: Understanding the Support for Affordable Housing Programs in Cities." University of North Carolina at Chapel Hill.

Basolo, Victoria, and David Lowery. 2010. "Delineating the Regional Market in Studies of Intercity Competition." Urban Geography 31 (3): 369-84.

Baylor University. 2010. The Baylor Religion Survey, Wave III. Waco: Baylor Institute for Studies of Religion [producer]. Beauregard, Robert A. 2015. Planning Matter: Acting with Things. 
Chicago: The University of Chicago Press.

Belsky, Eric S., Christopher E. Herbert, and Jennifer H. Molinsky.

2014. Homeownership Built to Last: Balancing Access, Affordability, and Risk after the Housing

Crisis. Washington, DC: Brookings Institution Press with the Joint Center for Housing Studies of Harvard University.

Betzold, Carola. 2013. "Business Insiders and Environmental Outsiders? Advocacy Strategies in International Climate Change Negotiations." Interest Groups and Advocacy 2 (3): 30222.

Beyers, Jan. 2004. "Voice and Access: Political Practices of European Interest Associations." European Union Politics 5 (2): 211-40.

Binderkrantz, Anne S. 2005. "Interest Group Strategies: Navigating between Privileged Access and Strategies of Pressure." Political Studies 53 (4): 694-715.

Binderkrantz, Anne S. 2008. "Different Groups, Different Strategies: How Interest Groups Pursue Their Political Ambitions." Scandinavian Political Science 31 (2): 173-200.

Bratt, Rachel G. 2012. "The Quadruple Bottom Line and Nonprofit Housing Organizations in the United States." Housing Studies 27:438-456.

Burstein, Paul, and April Linton. 2002. "The Impact of Political Parties, Interest Groups, and Social Movement Organizations on Public Policy: Some Recent Evidence and Theoretical Concerns." Social Forces 81:381-408.

Carroll, John S., and Eric J. Johnson. 1990. Decision Research: A Field Guide. Newbury Park: SAGE.

City of Pasadena. 2008. "General Plan, Housing Element 2008- 2014." https://tinyurl.com/y367n2eu.

City of Pomona California. n.d. "City Council." https://www. ci.pomona.ca.us/index.php/government/city-council.

Craig, Maureen A., Julian M. Rucker, and Jennifer A. Richeson. 2018. "The Pitfalls and Promise of Increasing Racial Diversity: Threat, Contact, and Race Relations in the 21st Century." Current Directions in Psychological Science 27 (3): 188-93.

Díaz McConnell, Eileen. 2017. "Rented, Crowded, and Unaffordable? Social Vulnerabilities and the Accumulation of Precarious Housing Conditions in Los Angeles." Housing Policy Debate 27 (1): 60-79.

Duncan, H. Daniels. 2004. "Advocacy and Nonprofit Organizations." In Philanthropy in America: A Comprehensive Historical Encyclopedia, edited by Dwight F. Burlingame, 9-11. Santa Barbara: ABC CLIO.

Edwards, Bob, and John D. McCarthy. 2009. "Resources and Social Movement Mobilization." In Blackwell Companion to Social Movements, edited by David A. Snow, Sarah A. Soule, and Hanspeter Kriesi, 116-52. Malden: Blackwell.

Eisinger, Peter K. 1973. "The Conditions of Protest Behavior in American Cities." American Political Science Review 67:11-28. Gamson, William A., and David S. Meyer. 1996. "Framing Political Opportunity." In Comparative Perspectives on Social Movements: Political Opportunities, Mobilizing Structures,

and Cultural Framings, edited by Doug McAdam, John D. McCarthy, and Mayer N. Zald, 275-90. Cambridge: Cambridge University Press. 
Garde, Ajay. 2016. "Affordable by Design? Inclusionary Housing Insights from Southern California." Journal of Planning Education and Research 36 (1): 16-31.

Glaser, Barney G. 1965. "The Constant Comparative Method of Qualitative Analysis." Social Problems 12:436-45.

Goetz, Edward G. 1995. Shelter Burden: Local Politics and Progressive Housing Policy. Philadelphia: Temple University Press.

Hirsch, Arnold R. 2000. "Containment on the Home Front: Race and Federal Housing Policy from the New Deal to the Cold War." Journal of Urban History 26 (2): 158-89.

Internal Revenue Service (n.d.). "2018 Instructions for Form 990 Return of Organization Exempt." http://www.irs.gov/pub/irs- pdf/i990.pdf.

Jenkins, J. Craig. 1983. "Resource Mobilization Theory and the Study of Social Movements." Annual Review of Sociology 9:527-53.

Jenkins, J. Craig, and Charles B. Perrow. 1977. "Insurgency of the Powerless: Farm Worker Movements (1946-1972)." American Sociological Review 42:249-68.

Jepperson, Ronald L. 1991. The New Institutionalism in Organizational Analysis. Edited by Walter W. Powell and Paul DiMaggio. Chicago: The University of Chicago Press.

Joint Center for Housing Studies. 2014. "State of the Nation's Housing Report. Rental Housing." Harvard University, Cambridge.

Long Beach. n.d. "City Officials." http://www.longbeach.gov/offi- cials/.

Los Angeles. n.d. "Form of Government." https://www.lacity.org/ government/popularinformation/form-government.

Lucio, Joanna, and Edgar Ramirez de la Cruz. 2012. "Affordable Housing Networks: A Case Study in the Phoenix Metropolitan Region." Housing Policy Debate 22:37-41.

Maclndoe, Heather, and Ryan Whalen. 2013. "Specialists, Generalists, and Policy Advocacy." Journal of Sociology and Social Welfare 40:119-49.

McAdam, Doug. 1996. "Introduction: Opportunities, Mobilizing Structures, and Framing Processes - Toward a Synthetic, Comparative Perspective on Social Movements." In Comparative Perspectives on Social Movements: Political Opportunities, Mobilizing Structures, and Cultural Framings, edited by Doug McAdam, John D. McCarthy, and Mayer N. Zald, 1-22. New York: Cambridge University Press.

McCarthy, John D., and Mayer N. Zald. 2002. "The Enduring Vitality of the Resource Mobilization Theory of Social Movements." In Handbook of Sociological Theory, edited by Jonathan H. Turner, 533-65. New York: Kluwer Academic/Plenum.

McCarthy, John D., and Mayer N. Zald. 1977. "Resource Mobilization and Social Movements." American Journal of Sociology 82:1212-41.

Meyer, David S. 1993. "Protest Cycles and Political Process: American Peace Movements in the Nuclear Age." Political Research Quarterly 46:451-79.

Meyer, David S. 2004. "Protest and Political Opportunities." Annual Review of Sociology 30:125-45.

Meyer, David S. 2009. The Politics of Protest: Social Movements in America. New York: Oxford University Press.

Meyer, David S., and Debra C. Minkoff. 2004. "Conceptualizing Political Opportunity." Social Forces 82 (June): 1457-92. 
Meyer, David S., and Sidney G. Tarrow. 1998. The Social Movement Society: Contentious Politics for a New Century. Lanham: Rowman \& Littlefield.

Nguyen, Mai Thi, Victoria Basolo, and Abhishek Tiwari. 2012. "Opposition to Affordable Housing in the USA: Debate Framing and the Responses of Local Actors." Housing, Theory and Society 30:107-30.

Pasadena. n.d. "City of Pasadena Government." https://www. cityofpasadena.net/government/.

Prakash, Aseem, and Mary K. Gugerty. 2010. "Trust but Verify? Voluntary Regulation Programs in the Nonprofit Sector." Regulation \& Governance 4 (1): 22-47.

Ross, Justin, Wenli Yan, and Craig L. Johnson. 2015. "The Public Financing of America's Largest Cities: A Study of City Financial Records in the Wake of the Great Recession." Journal of Regional Science 55:1113-38.

Scheller, Daniel S., and Anaid Yerena. 2018. "Neighborhood Concerns and Mobilization Patterns of Homeowners and Neighborhood Associations." Journal of Public Management and Social Policy 24 (2): 5.

Schwartz, Alex F. 2015. Housing Policy in the United States. New York: Routledge.

Sharp, Elaine B. 2005. "Cities and Subcultures: Exploring Validity and Predicting Connections." Urban Affairs Review 41 (2): 132-56.

Silverman, Robert M. 2008. "The Influence of Nonprofit Networks on Local Affordable Housing Funding: Findings from a National Survey of Local Public Administrators." Urban Affairs Review 44 (1): 126-41.

Snow, David A., Sarah A. Soule, and Hanspeter Kriesi. 2009a. "Get Up, Stand Up: Tactical Repertoires of Social Movements." In Blackwell Companion to Social Movements, edited by David A. Snow, Sarah A. Soule, and Hanspeter Kriesi, 262-93. Malden: Blackwell.

Snow, David A., Sarah A. Soule, and Hanspeter Kriesi. 2009b. "Introduction: Mapping the Terrain." In Blackwell Companion to Social Movements, edited by David A. Snow, Sarah A. Soule, and Hanspeter Kriesi, 3-16. Malden: Blackwell.

U.S. Census Bureau. 2010. "Census 2010 SF1 and SF3." http://factfinder.census.gov/servlet/BasicFactsServlet.

U.S. Housing and Urban Development. 2012. "U.S. Housing Market Conditions." http://www.huduser.org/portal/periodicals/ushmc.html.

Yerena, Anaid. 2015. "The Impact of Advocacy Organizations on Low-Income Housing Policy in U.S. Cities." Urban Affairs Review 51:843-70.

Yin, Robert K. 2009. Case Study Research: Design and Methods. Los Angeles: SAGE. 